\title{
Active Tectonics of the Saymareh-Karkheh River Basin (Northwest of Persian Gulf, Iran)
}

\author{
Negin Rahimi ${ }^{1}$, Mehran Arian ${ }^{*}$, Manochehr Ghorashi ${ }^{2}$ \\ ${ }^{1}$ Department of Geology, Science and Research Branch, Islamic Azad University, Tehran, Iran \\ ${ }^{2}$ Department of Geology, North Tehran Branch, Islamic Azad University, Tehran, Iran \\ Email: ${ }^{*}$ mehranarian@yahoo.com
}

How to cite this paper: Rahimi, N., Arian, M. and Ghorashi, M. (2017) Active Tectonics of the Saymareh-Karkheh River Basin (Northwest of Persian Gulf, Iran). Open Journal of Marine Science, 7, 238257.

https://doi.org/10.4236/ojms.2017.72017

Received: January 8, 2017

Accepted: April 8, 2017

Published: April 11, 2017

Copyright $\odot 2017$ by authors and Scientific Research Publishing Inc. This work is licensed under the Creative Commons Attribution International License (CC BY 4.0).

http://creativecommons.org/licenses/by/4.0/

\section{cc) (i) Open Access}

\begin{abstract}
Active tectonics is an indicator of recent movement of mountains and landscapes evolution for regions affected by current tectonic activity. The Saymareh-Karkheh river basin is located on the Zagros Mountain in the west Iran. The Zagros Mountain is an orogenic belt that is formed by the collision between the Eurasian and Arabian plates during Cenozoic. Active tectonics has analyzed by measurement of six geomorphic indices (hypsometric integral, basin asymmetry factor, basin shape, the stream length-gradient, mountain-front sinuosity and valley floor width-height ratio) which they combined to index of active tectonics (Iat). Based on values of this index, the Saymareh-Karkheh river basin was divided into high (Class 2, 18.8\%), moderate (Class 3, 70.3\%), and low (Class 4, 10.9\%) relative tectonic activity parts. The above results confirm the usefulness of geomorphic analyses for regional assessment of active tectonics they are compatible with differential tectonic activity in the High Zagros and Zagros fold and thrust belt. Also, it was revealed that geomorphic indices and using of GIS technics are very useful to investigation of active tectonics in the mountain areas.
\end{abstract}

\section{Keywords}

Saymareh, Geomorphic, Indices, Zagros, Iran

\section{Introduction}

The Saymareh River (with near to $400 \mathrm{~km}$ length) has been originated from the Zagros Mountains by combination of Gamasayab, Gharasu and Kashkan rivers and finally flows into the Hour-Al-Azim wetland on the Iran and Iraq border zone. The final segment of this river (with near to $200 \mathrm{~km}$ length) is called Karkheh River and totally, it is the third long river (about $755 \mathrm{~km}$ ) in Iran. The structures of the Zagros Mountains on the northeast margin of the Arabian plate reflect quaternary tectonics of this region. We have used a quantitative method 
to assessment of quaternary tectonics in the Saymareh-Karkheh river basin. In this paper, for the first time six geomorphic indices: hypsometric integral (Hi), the stream length-gradient (SL), asymmetry factor (Af), mountain-front sinuosity (Smf), valley floor width-valley height ratio (Vf) and basin shape (Bs) have analysed for comparison of different landforms [1]. Then, mean of above index or Iat has calculated for determination of relative active tectonics levels. Previously, this approach has been done in the USA by [2], Spain by [3].

\section{Geologic Setting}

The Saymareh-Karkheh river basin is located on the Zagros Mountain that is an orogenic belt in the southwest Iran. This mountain has formed due to convergent regime between the Arabian and Eurasian plates during Cenozoic. The Saymareh-Karkheh river basin $\left(51,341 \mathrm{~km}^{2}\right)$ is located on the Zagros [4]. The Zagros is underlain by Phanerozoic sedimentary sequences which it has been formed hundreds anticlines and synclines (Figure 1).

The anticlines and synclines have got NW-SE dominant striking in the study area. The folding intensity has decreased toward the southwest. The earthquakes in the study area have got high frequency and small to moderate magnitude, thus seismic analysis of active tectonics is difficult.

The main fault zones of the Saymareh-Karkheh river basin are Kabirkoh, Khoramabad, Kerend and Sahneh faults. The rock resistances have categorized based on rock types as: low (alluvial deposits, marl and conglomerate), moderate (gypsum, dolomitic limestone and gypsums marl), and high (limestone and sandstone) based on [3]. Figure 2 and Figure 3 show lithology and their

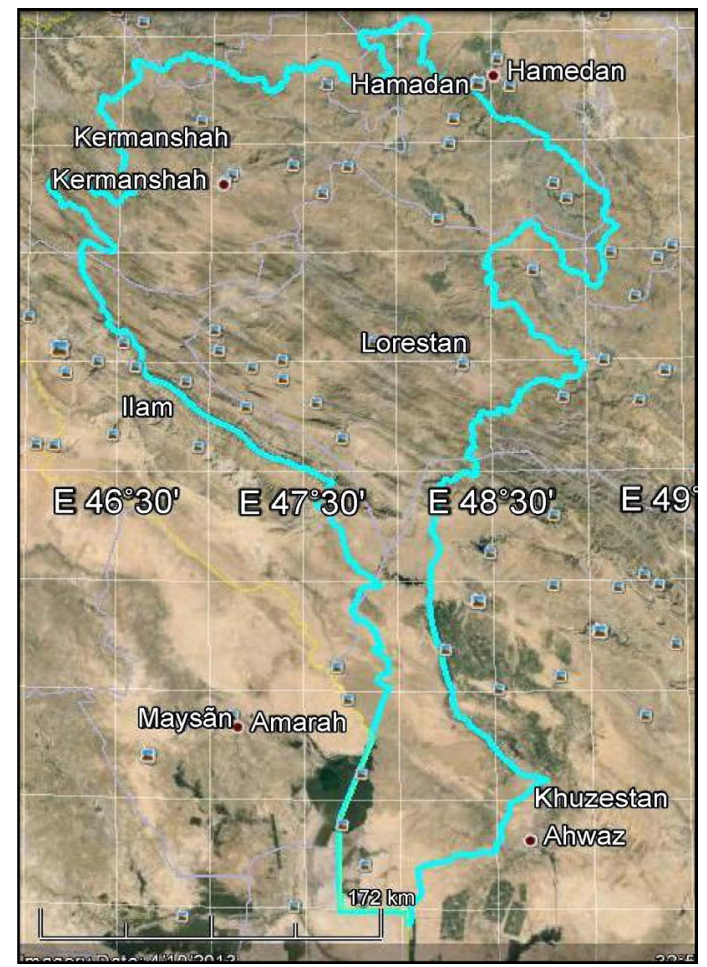

Figure 1. Location of the study area (Google Earth 2016). 


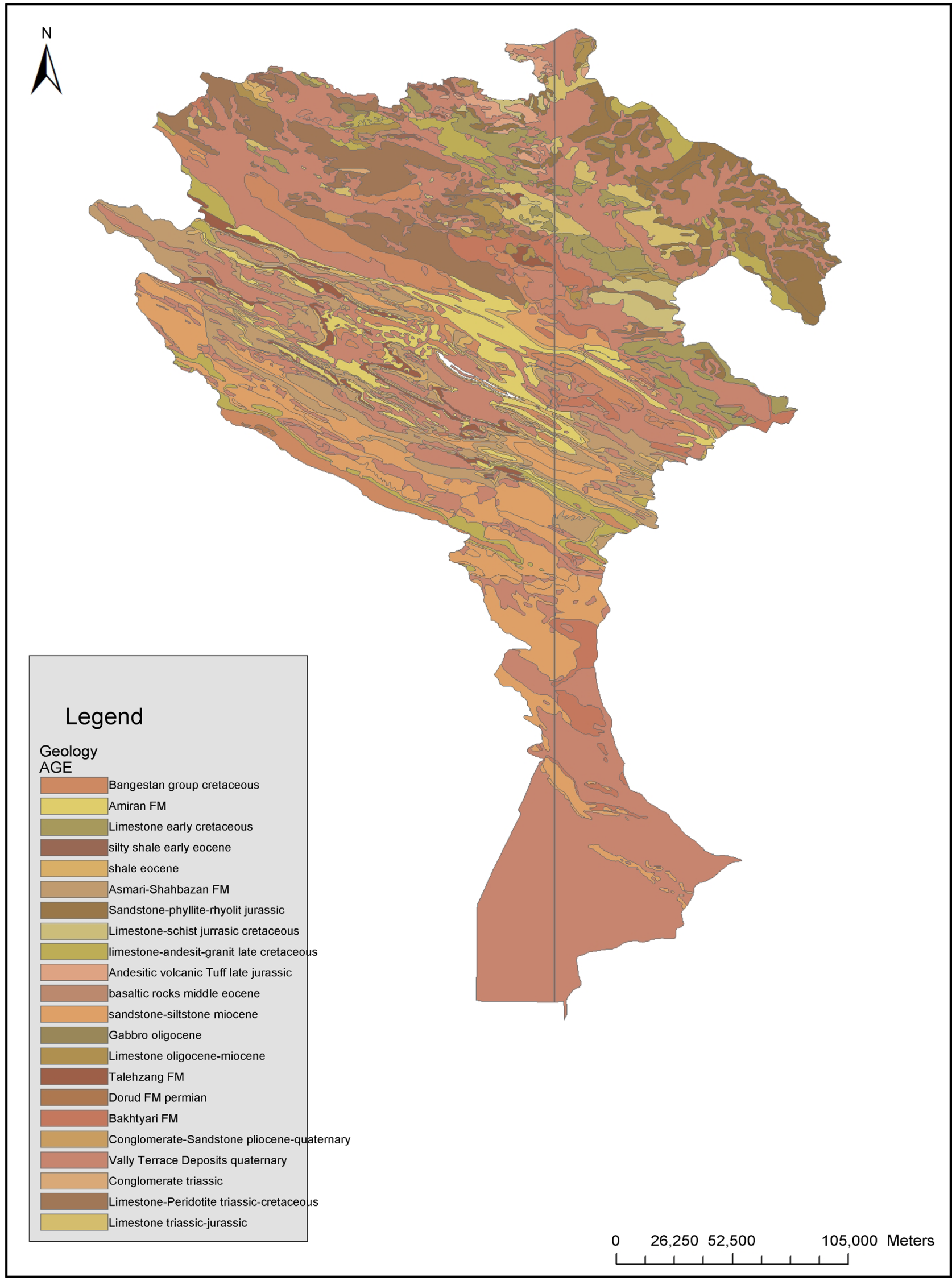

Figure 2. Geological map of the study area. 


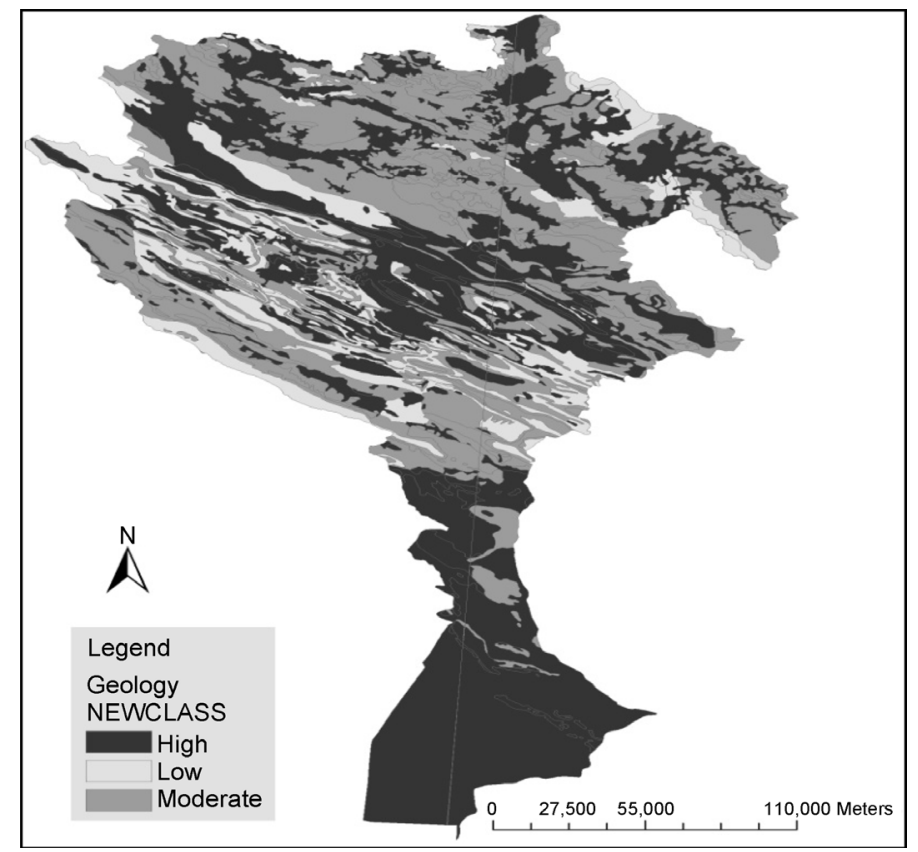

Figure 3. Distribution of rock strength levels.

resistant levels.

\section{Geomorphic Analysis}

Geomorphic indices are useful for quaternary tectonic investigation. We have measured six geomorphic indices mountain-front sinuosity (J), the streamlength gradient (SL), asymmetry factor (Af), hypsometric integral (Hi), basin shape (Bs), and valley floor width-valley height ratio (Vf). These indices have obtained for the Saymareh-Karkheh river basins, that flowing to the southwestward. This basin has divided into 35 sub-basins (Figure 4).

\subsection{Stream-Length Gradient}

Firstly, the stream-length gradient index has defined by [5] and it was used for many researchers such as [6].

To measure the values of this index, the drainage network and topographic maps are necessary. The contours distances are selected 20 meters.

The stream-length gradient index has calculated along all of sub-basins using a DEM based on topographic maps (for example sub-basin no.27 in Figure 5). Based on [3], the results are shown in Table 1 and Figure 6.

\subsection{Asymmetric Factor}

Firstly, the asymmetric factor (Af) has defined by [7]. The asymmetric factor varies from 19.8 (sub-basin no. 23) to 86.8 (sub-basin no. 4) in the study area and results are shown in Table 1 and Figure 6.

\subsection{Hypsometric Integral}

Firstly, the hypsometric integral (Hi) has defined by [8]. This index that shows 


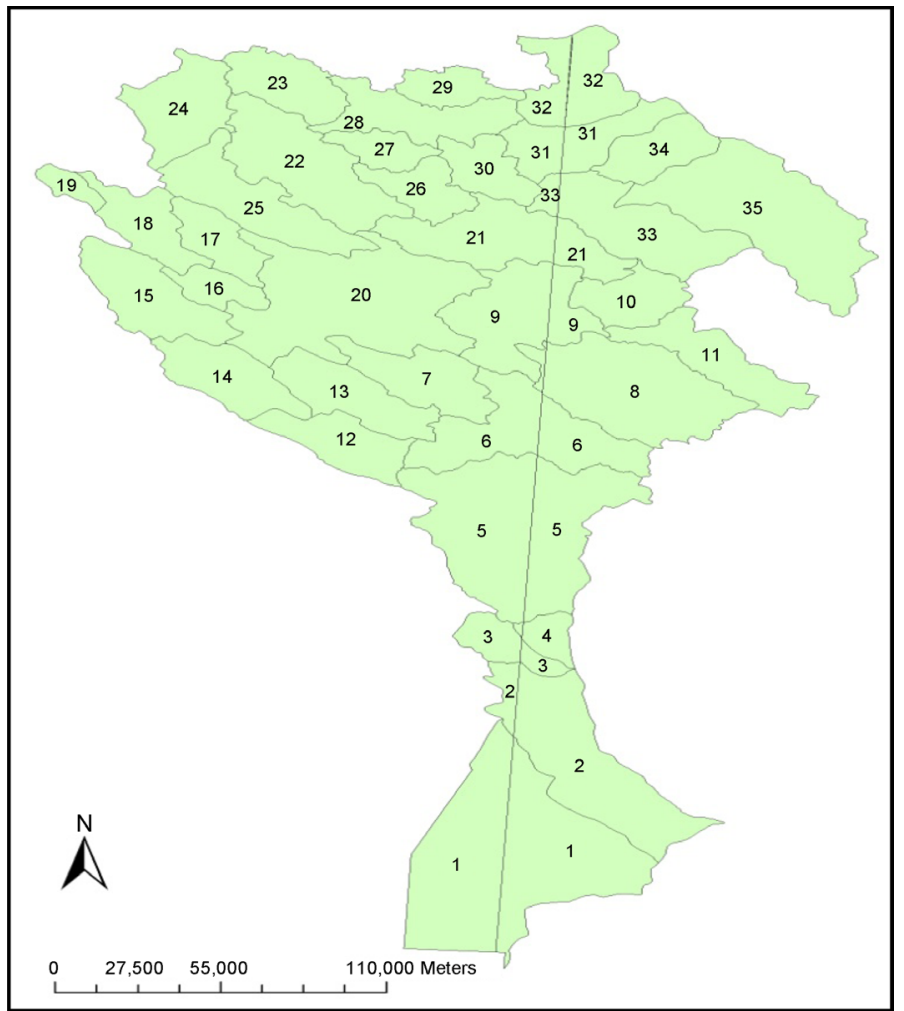

Figure 4. Thirty five sub-basins of the Saymareh-Karkheh river basin.

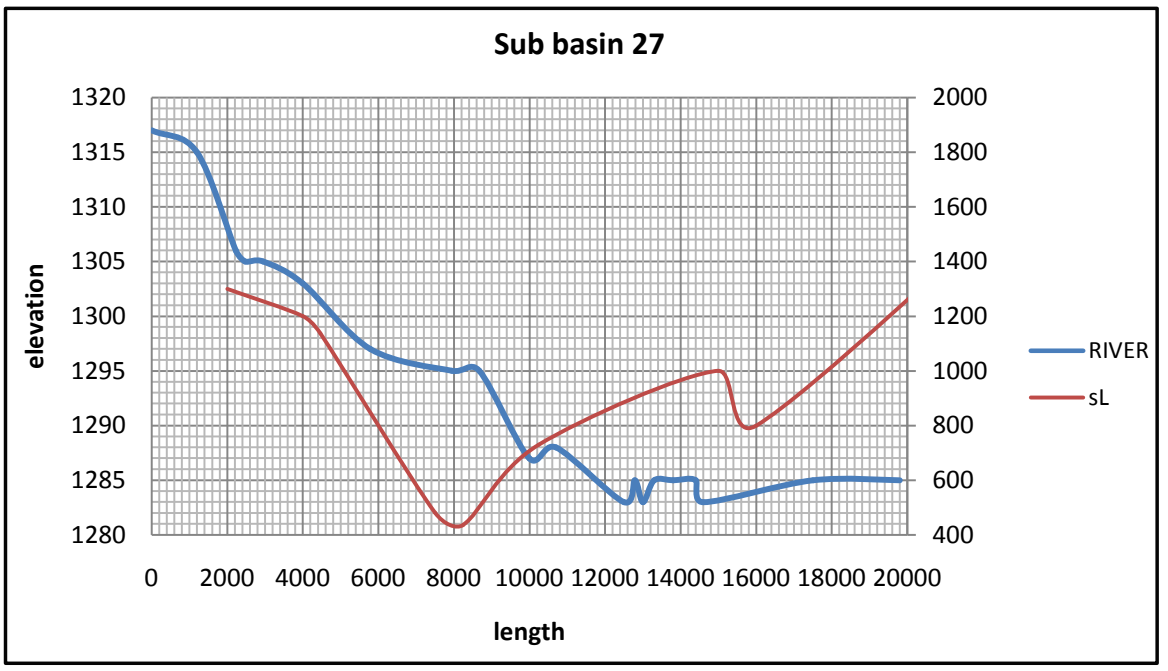

Figure 5. Longitudinal river profiles and measured SL values for three basins in the study area.

topographic maturity have calculated for all sub-basins. It ranges from 0.06 (sub-basin no. 1) to 0.47 (sub-basin no. 7). Then, the results have presented in Figure 7 and Table 1.

\subsection{Valley Floor Width to Valley Height Ratio}

Firstly, Valley floor width to valley height ratio (Vf) has defined by [9]. For measurement of this index, a distance varying from $2 \mathrm{~km}$ were set and the values 
Table 1. Values of geomorphic indices.

\begin{tabular}{|c|c|c|c|c|c|c|c|}
\hline Sub-basin & SL & Af & Bs & Smf & $\mathrm{Vf}$ & $\mathrm{Hi}$ & IAT \\
\hline 1 & - & 74.3 & 1.75 & - & - & 0.06 & 3 \\
\hline 2 & 57.94 & 68.3 & 4.46 & - & - & 0.25 & 2 \\
\hline 3 & 26.77 & 38.2 & 3.13 & 1.10 & 8.57 & 0.33 & 3 \\
\hline 4 & 85.21 & 86.8 & 1.69 & 1.08 & - & 0.27 & 3 \\
\hline 5 & 444.98 & 41.2 & 2.60 & $\begin{array}{l}1.03 \\
1.13\end{array}$ & $\begin{array}{c}3.47 \\
1.06 \\
2.96 \\
2.5\end{array}$ & 0.26 & 3 \\
\hline 6 & 304.80 & 31.3 & 2.91 & 1.04 & 0.47 & 0.32 & 2 \\
\hline 7 & 341.12 & 42.9 & 2.41 & 1.02 & - & 0.47 & 2 \\
\hline 8 & 272.48 & 65.7 & 1.94 & 1.05 & 1.96 & 0.31 & 3 \\
\hline 9 & 424.87 & 47.4 & 1.61 & $\begin{array}{l}1.07 \\
1.08\end{array}$ & 0.56 & 0.35 & 3 \\
\hline 10 & 450.58 & 39.0 & 1.30 & - & - & 0.29 & 3 \\
\hline 11 & 418.91 & 61.2 & 4.01 & 1.08 & 0.55 & 0.26 & 2 \\
\hline 12 & 878.38 & 69.6 & 2.55 & $\begin{array}{l}1.04 \\
1.13 \\
1.21\end{array}$ & - & 0.25 & 2 \\
\hline 13 & 983.94 & 54.2 & 1.83 & 1.08 & - & 0.46 & 2 \\
\hline 14 & 525.95 & 66.2 & 2.90 & 1.08 & - & 0.31 & 2 \\
\hline 15 & 756.58 & 68.3 & 2.52 & 1.08 & 0.33 & 0.36 & 2 \\
\hline 16 & 383.94 & 30.3 & 1.95 & - & - & 0.30 & 3 \\
\hline 17 & 1022.7 & 61.1 & 2.00 & - & 30.90 & 0.24 & 3 \\
\hline 18 & 604.47 & 39.0 & 2.39 & 1.13 & - & 0.20 & 3 \\
\hline 19 & 1721.16 & 33.5 & 2.25 & - & - & 0.25 & 2 \\
\hline 20 & 288.08 & 56.4 & 1.34 & 1.14 & 0.40 & 0.35 & 3 \\
\hline 21 & 178.07 & 63.5 & 2.75 & - & - & 0.35 & 4 \\
\hline 22 & 1193.43 & 54.4 & 2.71 & 1.19 & 2.35 & 0.13 & 3 \\
\hline 23 & 289.25 & 19.8 & 1.27 & 1.1 & - & 0.28 & 3 \\
\hline 24 & 325.89 & 52.1 & 1.12 & 1.13 & - & 0.18 & 4 \\
\hline 25 & 165.79 & 46.1 & 3.83 & 1.13 & $\begin{array}{l}2.85 \\
1.81\end{array}$ & 0.21 & 4 \\
\hline 26 & 742.41 & 27.1 & 1.18 & 1.19 & 8.10 & 0.17 & 3 \\
\hline 27 & 1798.3 & 81.6 & 2.29 & - & - & 0.33 & 2 \\
\hline 28 & 301.20 & 47.0 & 2.29 & $\begin{array}{l}1.1 \\
1.0\end{array}$ & $\begin{array}{l}1.12 \\
1.11\end{array}$ & 0.36 & 4 \\
\hline 29 & 380.89 & 66.9 & 1.99 & - & - & 0.21 & 3 \\
\hline 30 & 747.46 & 62.0 & 2.05 & $\begin{array}{c}1.0 \\
1.19\end{array}$ & 1.06 & 0.22 & 3 \\
\hline 31 & 304.56 & 61.9 & 2.20 & 1.23 & 3.63 & 0.17 & 3 \\
\hline 32 & 834.34 & 52.5 & 1.14 & 1.22 & 1.25 & 0.26 & 3 \\
\hline 33 & 428.81 & 47.7 & 3.28 & $\begin{array}{l}1.04 \\
1.17 \\
1.35\end{array}$ & $\begin{array}{l}3.40 \\
0.38 \\
0.86\end{array}$ & 0.21 & 3 \\
\hline 34 & 287.72 & 56.4 & 1.97 & 1.04 & $\begin{array}{l}6.85 \\
1.37\end{array}$ & 0.22 & 4 \\
\hline 35 & 870.76 & 54.4 & 2.61 & 1.17 & $\begin{array}{l}4.65 \\
3.40\end{array}$ & 0.27 & 3 \\
\hline
\end{tabular}




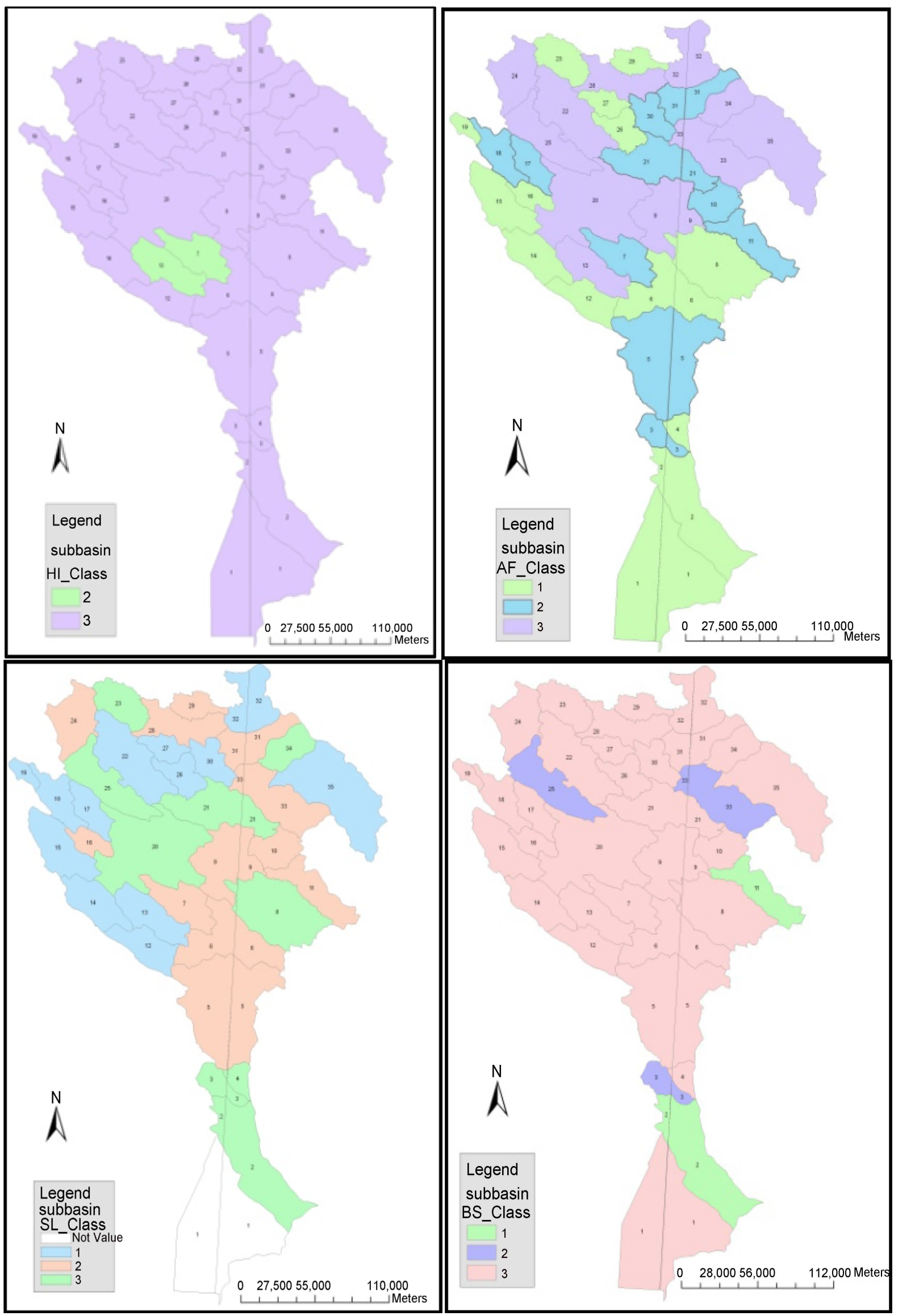




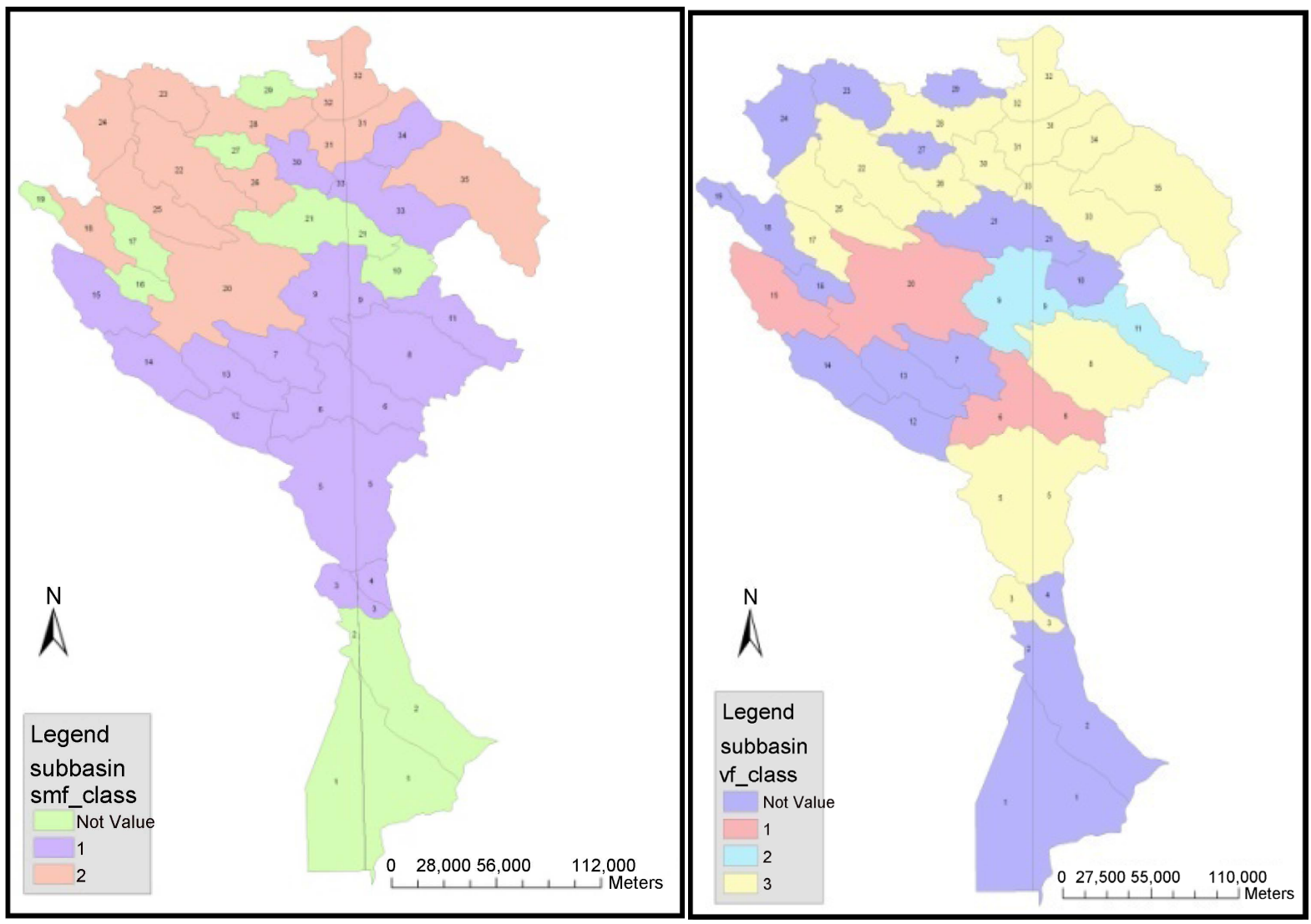

Figure 6. Distribution of six index and classification of them into three classes.
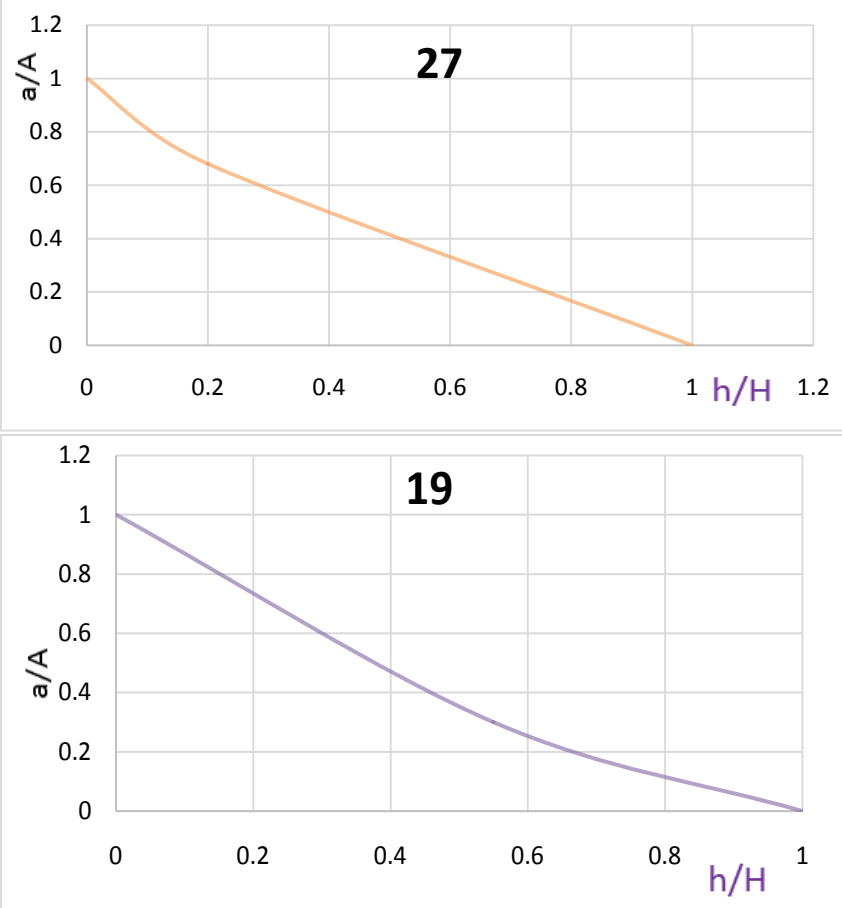

Figure 7. Hypsometry curves of two sub-basins (no. 19, 27). 
have measured from topographic maps (Figure 6 and Figure 8). The results are shown in Table 1. The range of Vf is from 0.33 (sub-basin no. 15) to 30.9 (sub-basin no. 17).

\subsection{Basin Shape}

Firstly, the basin shape index (Bs) has defined by [10]. This index has calculated by using the topographic maps and the results are shown in Figure 6 and Table 1. The basin shape index ranges from 1.12 (sub-basin no. 24) to 4.46 (sub-basin no. 2).

\subsection{Mountain Front Sinuosity}

Firstly, the mountain front sinuosity index (J) has defined by [9]. We were measured the mountain front sinuosity index for 23 mountain fronts (Figure 6

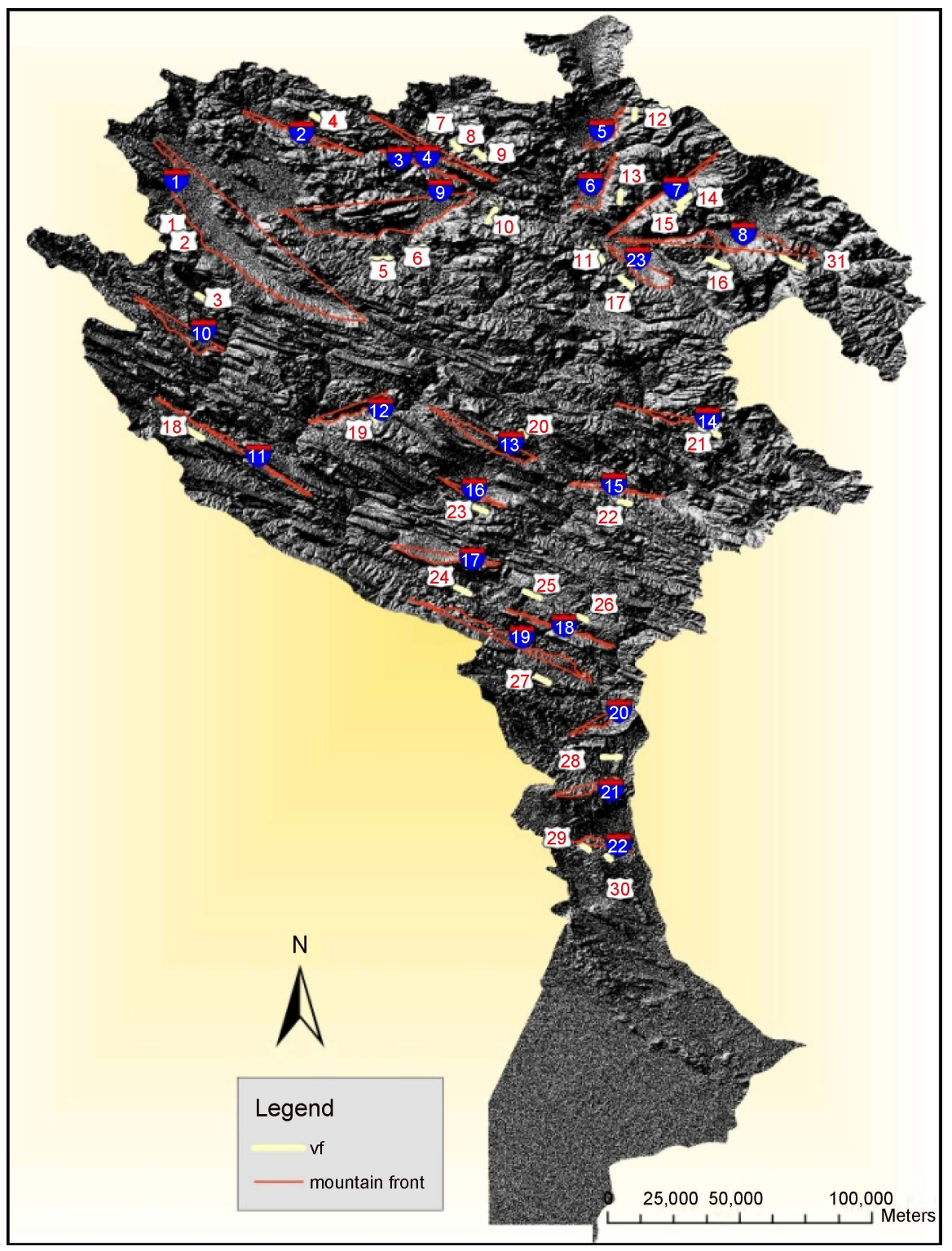

Figure 8. Location of sections for Smf and Vf calculations. 
and Figure 8) by using SRTM images. Our results are shown in Table 1.

\section{Results and Discussion}

Based on previous work on the salt and mud diapirism [11]-[30] and neotectonic regime in Iran [31]-[36], Zagros in south Iran is the most active zone [37]-[76]. Then, Alborz [77]-[123] and Central Iran [124]-[152] have been situated in the next orders. Thus, the study area has been affected by an important regional shortening, but this research tried to evaluate levels of relative tectonic activities in a wider region by using of six geomorphic indices. The averages of these indices have used to investigation in the Saymareh-Karkheh river basin. The values have divided into very high, high, moderate and low levels and their distribution are shown in Table 1 (IAT column) and Figure 9.

Figure 9 shows the result of the classification for each basin; $23.7 \%(12,180$ $\left.\mathrm{km}^{2}\right)$ to Class 2; $62.9 \%\left(32,318 \mathrm{~km}^{2}\right)$ to Class 3; and $13.3 \%\left(6843 \mathrm{~km}^{2}\right)$ to Class 4.

The Sahneh fault zone is the most important part, based on Iat and connects the Morvarid fault in the NW to the Nahavand fault in the SE. Tectonically, the mechanism of the Sahneh fault is high angle reverse with dextral strike slip component, and is compatible with the earthquakes focal mechanism solution, movement of the Arabian plate.

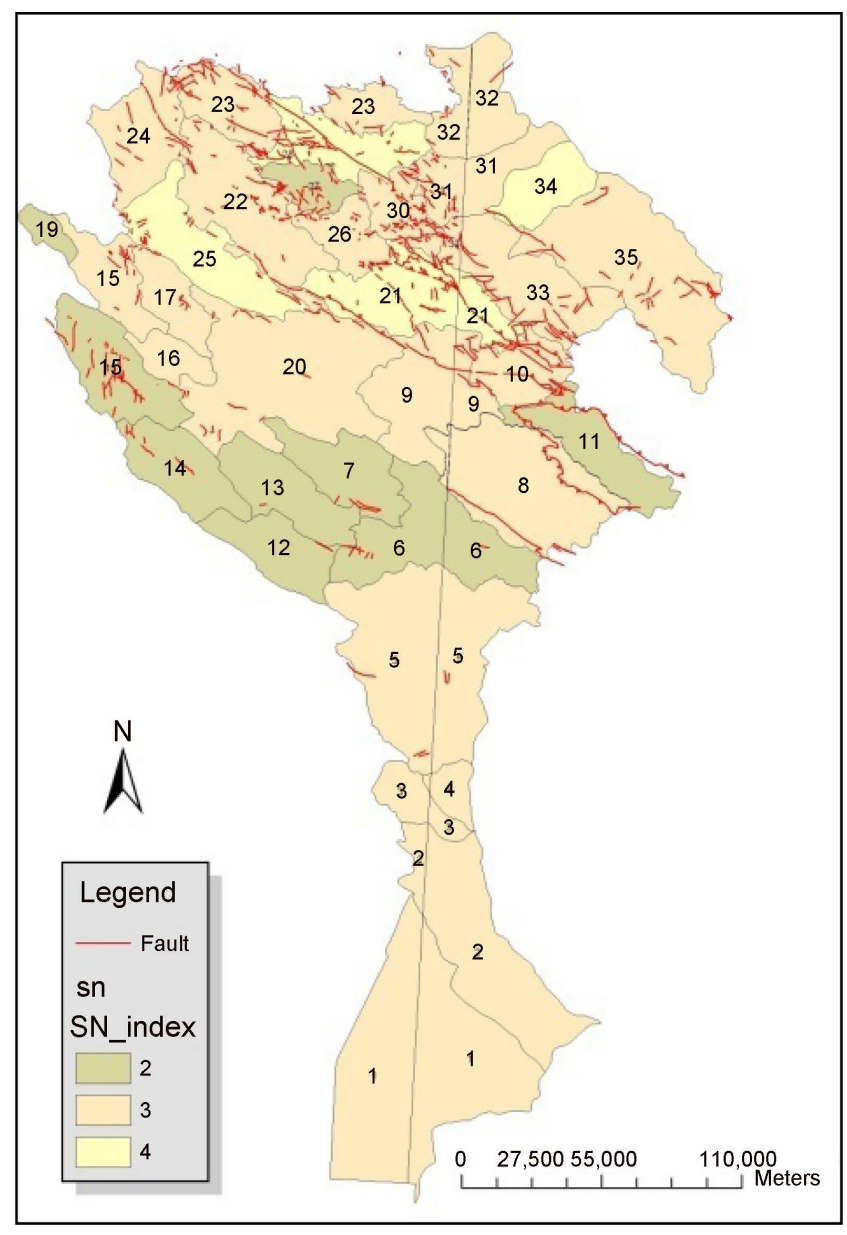

Figure 9. Distribution of Iat classes. 


\section{Conclusions}

The Saymareh-Karkheh river basin in the southwest Iran was selected for investigation of above quantitative method. Six geomorphic indices have measured in the Saymareh-Karkheh river basin. Finally, index of active tectonics was measured by combination of the below geomorphic indices; valley floor width-valley height ratio, mountain-front sinuosity, stream-length gradient, hypsometric integral, drainage basin asymmetry factor and basin shape.

The high values of Iat were found along longitudinal fault of Zagros Mountain such as Sahneh fault zone. The most parts have got moderate levels of active tectonics, because they have shown class 3. Also, the low values of Iat have located on plains and un-faulted areas.

\section{Acknowledgements}

This work has been funded by department of geology, Islamic Azad University, Science and Research branch, Tehran, Iran. Also, special thanks to vice-president for research in Science and Research branch, Tehran.

\section{References}

[1] Abdideh, M., Qorashi, M., Rangzan, K. and Arian, M. (2011) Assessment of Relative Active Tectonics Using Morphometric Analysis, Case Study of Dez River (Southwestern, Iran). Geosciences, 20, 33-46.

[2] Abdolizadeh, S., Maleki, Z. and Arian, M. (2016) Earthquake Hazard Zonation and Seismotectonics of the Bandar Abbas Area, Zagros, Iran. Open Journal of Geology, 6, 210-224. https://doi.org/10.4236/ojg.2016.63019

[3] Alavi, M. (2004) Regional Stratigraphy of the Zagros Fold-Thrust Belt of Iran and Its Proforeland Evolution. American Journal of Science, 304, 1-20. https://doi.org/10.2475/ajs.304.1.1

[4] Alizadeh, H. and Arian, M. (2015) Rule of Structural Factors in Formation of Porphyry Copper Deposits in South Western Part of Kerman Area, Iran. Open Journal of Geology, 5, 489-498. https://doi.org/10.4236/ojg.2015.57045

[5] Alizadeh, H., Arian, M., Lotfi, M., Ghorashi, M. and Ghorbani, M. (2015) Determination of Porphyry Copper Deposit Locations Using Photo Lineament Factor in Northern Parts of the Dehaj-Sardoiyeh Belt. Geosciences, 24, 247-252.

[6] Alladin, Y., Talebian, M., Arian, M. and Ahmadi, M.M. (2015) Geotechnical Investigation and Seismic Zonation of Alluvial Deposits in Western Tehran. Geosciences, 24, 333-342.

[7] Aram, Z. and Arian, M. (2016) Active Tectonics of the Gharasu River Basin in Zagros, Iran, Investigated by Calculation of Geomorphic Indices and Group Decision Using Analytic Hierarchy Process (AHP) Software. Episodes, 39, 39-44. https://doi.org/10.18814/epiiugs/2016/v39i1/89235

[8] Arian, M., Ahmadipour, M.R. and Khodaei, K. (2003) The Elements of Fold Style in Soltananticline, Northeast of Pole Dokhtar. Iranian Journal of Geology, 1, 1-8.

[9] Arian, M. (2010) Applied Seismotectonics. Farazamin Press, Tehran, 304 p.

[10] Arian, M. (2010) Earthquake-Fault Hazard Investigations in the Kerman Quadrangle. Journal of Sciences, 19, 176-182.

[11] Arian, M. (2010) Tectonics and Sedimentation. Farazamin Press, Tehran, 307 p. 
[12] Arian, M. (2011) A Preface on Salt Diapirism of Iran. AsarNafis Press, Qum, 309 p.

[13] Arian, M. (2011) Basement Tectonics and Geology of Iran. AsarNafis Press, Qum, $300 \mathrm{p}$.

[14] Arian, M. (2011) Middle East Tectonics. AsarNafis Press, Qum, 236 p.

[15] Arian, M. (2012) Clustering of Diapiric Provinces in the Central Iran Basin. Carbonates and Evaporites, 27, 9-18. https://doi.org/10.1007/s13146-011-0079-9

[16] Arian, M. (2012) Salt Diapirism and Tectonics. 2nd Edition, AsarNafis Press, Qum, $319 \mathrm{p}$.

[17] Arian, M. (2013) Physiographic-Tectonic Zoning of Iran's Sedimentary Basins. Open Journal of Geology, 3, 169-177. https://doi.org/10.4236/ojg.2013.33020

[18] Arian, M. (2015) Seismotectonic-Geologic Hazards Zoning of Iran. Earth Sciences Research Journal, 19, 7-13. https://doi.org/10.15446/esrj.v19n1.40664

[19] Arian, M. and Aram, Z. (2014) Relative Tectonic Activity Classification in the Kermanshah Area, Western Iran. Solid Earth, 5, 1277-1291. https://doi.org/10.5194/se-5-1277-2014

[20] Arian, M. and Bagha, N. (2012) Active Tectonics of Tehran Area, Iran. Journal of Basic and Applied Scientific Research, 2, 3805-3819.

[21] Arian, M. and Feizi, F. (2005) Application of Geomorphic Indices to the Assessment of Relative Tectonic Activity Levels in the Alborz-Central Iran Border Zone. Journal of Sciences, 15, 378-403.

[22] Arian, M. and Feizi, F. (2010) The Significance of Faulting on the Surficial Spreading of Evaporitic Deposits in the Varamin-Semnan Area. Journal of Earth and Resources, 3, 1-20.

[23] Arian, M. and Hashemi, A. (2008) Seismotectonic Zoning in the Zagros. Journal of Sciences, 18, 63-76.

[24] Arian, M. and Khodabakhshnezhad, A. (2015) Sedimentary Environments Can Be Changed by Geotechnology (Case Study: A Morphotectonic Idea for Design of Extensive Artificial Bay on the Iranian Plateau). International Journal of Geosciences, 6, 487-496. https://doi.org/10.4236/ijg.2015.65039

[25] Arian, M. and Maleki, R. (2008) Neotectonics. Farazamin Research Center, Tehran, 150.

[26] Arian, M. and Maleki, Z. (2010) Principals of Experimental Tectonics. AsarNafis Publication, Qum, 224 p.

[27] Arian, M. and Noroozpour, H. (2015) Seismic Activity and Fractal Geometry of Kareh Bas Fault System in Zagros, South of Iran. Open Journal of Geology, 5, 291299. https://doi.org/10.4236/ojg.2015.55026

[28] Arian, M. and Noroozpour, H. (2015) Tectonic Geomorphology of Iran's Salt Structures. Open Journal of Geology, 5, 61-72. https://doi.org/10.4236/ojg.2015.52006

[29] Arian, M. and Noroozpour, H. (2015) The Biggest Salt-Tongue Canopy of Central Iran. Open Journal of Geology, 5, 55-60. https://doi.org/10.4236/ojg.2015.52005

[30] Arian, M. and Nouri, R. (2015) Lineament Tectonics and Mineralization in Tarom Area, North Iran. Open Journal of Geology, 5, 115-125. https://doi.org/10.4236/ojg.2015.53011

[31] Arian, M. and Pourkermani, M. (2001) Rivers Morphology and Active Tectonic (Reviewing the Current Status of GhezelOzon River in the Province of Zanjan). Proceedings of the 5 th Conference of Geological Society of Iran, Tehran, 28-30 August 2001, 556. 
[32] Arian, M. and Pourkermani, M. (2004) Structural Significance of North Semnan and Attary Faults in Alborz-Central Iran Border Zone. Journal of Science, 14, 45514569.

[33] Arian, M. and Pourkermani, M. (2004) Tectonic Elements of South Flank in the East-Central Alborz Mountain. Journal of Sciences, Teacher Training University, 4, 359-368.

[34] Arian, M. and Pourkermani, M. (2005) Cenozoic Diastrophism and Deformational Events in the Southern Flank of Central-East Alborz. Journal of Faculty Earth Sciences, 10, 43-51.

[35] Arian, M. and Qorashi, M. (2006) The Movement Potential Evaluation of the Major Quaternary Faults in Alborz-Central Iran Border Zone, from the East of Tehran to the East of Semnan. Journal of Geosciences, Geological Survey of Iran, 15, 184-188.

[36] Arian, M. and Sistanipour, A. (2015) Mud Diapirism on the Gorgan, North Iran. Open Journal of Geology, 5, 442-450. https://doi.org/10.4236/ojg.2015.56041

[37] Arian, M. and Mohammadian, R. (2011) Analysis of Fractures in the Asmari Reservoir of Marun Oil Field (Zagros, Iran). Geosciences, 20, 87-96.

[38] Arian, M. (2003) Seismotectonic and Earthquake-Fault Hazard Investigations in the Kerman Region. Research Institute of Applied Sciences.

[39] Arian, M., Ahmadnia, A., Qorashi, M. and Pourkermani, M. (2002) Structural Analysis of Mengharak Transcurrent Fault System in Zagros, Iran. Special GEO 2002 Conference Issue Geoarabia, 7, 209-210.

[40] Arian, M., Alizadeh, H. and Noroozpour, H. (2011) Satellite Geometry of Faults and Fractures and Its Relationship with Porphyry Deposits in Northern Parts of Dahaj-Sardoiyeh Belt, South of Iran. Indian Journal of Science and Technology, 4, 1303-1306.

[41] Arian, M. and Pourkermani, M. (2005) The Elements of Fold Style Analysis in the Alborz-Central Iran Border Zone (From the East of Varamin to the East of Semnan). Journal of Science, 5, 569-584.

[42] Arian, M., Bagha, N., Khavari, R. and Noroozpour, H. (2012) Seismic Sources and Neo-Tectonics of Tehran Area (North Iran). Indian Journal of Science and Technology, 5, 2379-2383.

[43] Arian, M., Maleki, Z. and Noroozpour, H. (2011) Cenozoic Diastrophism and Deformational Events in the East Central Alborz. Journal of Basic and Applied Scientific Research, 1, 2394-2400.

[44] Arian, M., Pourkermani, M., Khodabakhshnezhad, A. and Noroozpour, H. (2011) Investigation of Oil Trap in the Asmari Anticline (Zagros, Iran). Indian Journal of Science and Technology, 4, 1696-1699.

[45] Arian, M., Pourkermani, M., Qorashi, M. and Ghasemi, M.R. (2003) North Semnan Fault System and Its Role on Basin Division. Proceedings of the 8th Symposium of Geological Society of Iran, Shahrood, 4-6 September 2003, 11-17.

[46] Arian, M., Pourkermani, M., Sistanipour, A. and Noroozpour, H. (2011) Kinematic Significance of Fold- and Fault-Related Fracture Systems in the Rafsanjan's Northeast Highlands (Central Iran). Journal of Basic and Applied Scientific Research, 1, 3398-3406.

[47] Arian, M., Pourkermani, M., Sistanipour, A. and Noroozpour, H. (2011) Seismicity and Fault Segmentation of Bafq-Baghin Fault System (Central Iran). Journal of Applied Environmental and Biological Sciences, 1, 382-396.

[48] Arian, M., Qorashi, M. and Ahmadnia, A. (2003) Analysis of Behbahan Shear Zone. Iranian Journal of Geology, 1, 1-4. 
[49] Arian, M., Qorashi, M., Pourkermani, M. and Ahmadnia, A. (2003) Fractal Analysis of Mengharak Transcurrent Fault System in Zagros, Iran. Proceedings of the 4 th International Conference on Seismology and Earthquake Engineering, Tehran, 1214 May 2003, 23.

[50] Arian, M., Qorashi, M., Pourkermani, M. and Ahmadnia, A. (2006) The Structural Significance Kareh Bas Transcurrent Fault System in the Zagros Fold and Thrust Belt. Geosciences, 15, 126-133.

[51] Arian, M. and Sorbi, A. (2011) Remote Sensing Investigation of the Faults and Lineaments in the Karaj-Qazvin Region. Journal of the Earth, 5, 21-34.

[52] Arian, M., Toudeshki, V.H. and Noroozpour, H. (2011) Active Tectonics of QezelOzan River Basin, NW Iran. Journal of Applied Environmental and Biological Sciences, 1, 291-295.

[53] Arian, M., Komijani, A., Solgi, A. and Rahimi, N. (2010) Seismotectonics and Seismic Risk Analysis of Dez Flow Dam Site. Journal of Earth and Resources, 3, 1-14.

[54] Asadian, F. and Arian, M. (2009) Identification of Diapiric Provinces of Central Iran through Geological and Geographical Analysis. International Journal of Agriculture Environment \& Biotechnology, 2, 3443-3451.

[55] Asadian, F., Pourkermani, M. and Arian, M. (2007) Tectonic Geomorphology of Salt Structures in the Garmsar-Lasjerd Area. Geographical Research, 39, 75-84.

[56] Badrkhani, M., Maleki, Z. and Arian, M. (2016) Folding Style Analysis of the Tabnak Sweet Gas Field, Zagros, Iran. Open Journal of Geology, 6, 971-981.

https://doi.org/10.4236/ojg.2016.68073

[57] Bagha, N., Arian, M., Ghorashi, M., Pourkermani, M., El Hamdouni, R. and Solgi, A. (2014) Evaluation of Relative Tectonic Activity in the Tehran Basin, Central Alborz, Northern Iran. Geomorphology, 213, 66-87.

[58] Bagha, N., Ghorashi, M., Arian, M., Pourkermani, M. and Solgi, A. (2015) Neotectonic Analysis of Mosha-North Tehran Fault Zone, Based on Morphotectonic Features, Central Alborz, Northern Iran. Geosciences, 24, 41-52.

[59] Baharvand, S., Pourkermani, M., Ajalloian, R., Arian, M. and Nouryazdan, A.R. (2010) Seymareh Landslide and Its Role in Environmental and Geomorphologic Changes of the Pole-Dokhtar Area. Journal of the Earth, 4, 13-24.

[60] Bahiraee, S., Arian, M., Qorashi, M. and Solgi, M. (2015) The Movement Potential Evaluation of the Mosha Fault (The West of Firoozkuh to the Shahrestanak). Geosciences, 24, 123-126.

[61] Baratpour, F., Arian, M. and Solgi, A. (2015) Geometric Analysis of Tukak and Kamarun Anticlines on Izeh Zone, Zagros. Geosciences, 24, 191-200.

[62] Bazarchi, S., Jafari, M.R. and Arian, M. (2012) Geochemical Studies and Introduction of Anomaly Zones in Kandelus Sheet (Southwest of Baladeh). Journal of the Earth, 6, 67-75.

[63] Bull, W.B. (2007) Tectonic Geomorphology of Mountains: A New Approach to Paleoseismology. Blackwell, Malden. https://doi.org/10.1002/9780470692318

[64] Bull, W.B. and McFadden, L.D. (1977) Tectonic Geomorphology North and South of the Garlock Fault, California. In: Doehring, D.O., Ed., Geomorphology in Arid Regions. Proceedings of the Eighth Annual Geomorphology Symposium, State University of New York, Binghamton, 115-138.

[65] Cannon, P.J. (1976) Generation of Explicit Parameters for a Quantitative Geomorphic Study of Mill Creek Drainage Basin. Oklahoma Geology Notes, 36, 3-16.

[66] Chegini, A., Sorbi, A. and Arian, M. (2015) Active Tectonics of Hamedan Area, SW 
Iran by Index of Active Tectonics. International Journal of Geology, 4, 108-118.

[67] Daryani, N.J., Arian, M. and Omran, N.R. (2015) Tectonics and Mineralisation of Copper in the Ardestan-Kahang Area, Central Iran by Remote Sensing. Open Journal of Geology, 5, 188-196. https://doi.org/10.4236/ojg.2015.54017

[68] Dehbozorgi, M., Pourkermani, M., Arian, M., Matkan, A.A., Motamedi, H. and Hosseiniasl, A. (2010) Quantitative Analysis of Relative Tectonic Activity in the

[69] Ehsani, J. and Arian, M. (2015) Quantitative Analysis of Relative Tectonic Activity in the Jarahi-Hendijan Basin Area, Zagros, Iran. Geosciences Journal, 19, 751-765. https://doi.org/10.1007/s12303-015-0016-3

[70] Ehsani, J., Arian, M. and Ghorashi, M. (2015) Geomorphic Signatures of Active Tectonics in the Jarahi-Hendijan Drainage Basin in the South West Iran. Geosciences, 24, 211-218.

[71] El Hamdouni, R., Irigaray, C., Fernandez,T., Chacón, J. and Keller, E.A. (2008) Assessment of Relative Active Tectonics, Southwest Border of Sierra Nevada (Southern Spain). Geomorphology, 96, 150-173.

[72] Eshghi, Z., Arian, M. and Pourkermani, M. (2012) Structural Investigation on the Lak Mining Area (Bueen Zahra) Based on Remote Sensing, Used for Its Mineralization. Journal of the Earth, 6, 145-155.

[73] Farrokhnia, A.R., Pirasteh, S., Pourkermani, M. and Arian, M. (2011) Geo-Information Technology for Mass Wasting Hazard Zonation: Central-West Alborz-Iran. Disaster Advances, 4, 24-33.

[74] Farrokhnia, A.R., Pirasteh, S., Pradhan, B., Pourkermani, M. and Arian, M. (2011) A Recent Scenario of Mass Wasting and Its Impact on the Transportation in Alborz Mountains, Iran Using Geo-Information Technology. Arabian Journal of Geosciences, 4, 1337-1349. https://doi.org/10.1007/s12517-010-0238-7

[75] Feizi, F. and Arian, M. (2006) The Classification of Thrust Fronts in the Alborz-Central Iran Border Zone from the East of Varamin to the East of Semnan. Journal of Sciences, 16, 75-87.

[76] Feizi, F. and Arian, M. (2011) The Role of Structural Controllers in Geneses of Copper Deposits in 1:50000 Map of Saiin Qaleh. Journal of Sciences, 21, 1-10.

[77] Feizi, F., Arian, A. and Rahmani, R. (2007) Seismotectonic Zoning in the Eastern Part of the Central Alborz. Journal of Sciences, 17, 151-164.

[78] Feizi, F., Arian, M. and Arian, A. (2015) Mud Diapirism on the Makran, Iran: Case Study on the Napag Mud Volcano. Open Journal of Geology, 5, 300-308. https://doi.org/10.4236/ojg.2015.55027

[79] Gholamhosein Fard, N., Sorbi, A. and Arian, M. (2015) Active Tectonics of Kangavar Area, West Iran. Open Journal of Geology, 5, 422-441. https://doi.org/10.4236/ojg.2015.56040

[80] Hack, J.T. (1957) Studies of Longitudinal Stream-Profiles in Virginia and Maryland: U.S. Geological Survey Professional Paper, 294B, 45-97.

[81] Hadizadeh, A., Arian, M. and Ganjouyan, M.A. (2011) Analysis Geometry Dashtak Detachment Zone in the Dashtak, Salamati and Sepidar Anticlines from Interior and Sub Coastal Fars Area. Journal of the Earth, 6, 33-44.

[82] Hare, P.W. and Gardner, T.W. (1985) Geomorphic Indicators of Vertical Neotectonism along Converging Plate Margins, Nicoya Peninsula, Costa Rica. In: Morisawa, M. and Hack, J.T., Eds., Tectonic Geomorphology. Proceedings of the 15th Annual Binghamton Geomorphology Symposium, Allen and Unwin, Boston, 123134.

[83] Keller, E.A. and Pinter, N. (2002) Active Tectonics: Earthquakes, Uplift, and Land- 
scape. 2nd Edition. Prentice Hall, Upper Saddle River.

[84] Keynezhad, A., Pourkermani, M., Arian, M. and Saeedi, A. (2011) Dynamic Analysis of Fractures in North of Torud-Moalleman Area (Central Iran, East South of Damghan). Geosciences, 20, 3-16.

[85] Keynezhad, A., Pourkermani, M., Arian, M., Saeedi, A. and Lotfi, M. (2010) Research on Fractures in North of the Torud-Moalleman Area (Central Iran, Southeastern of Damghan) and Their Relation with Mineralization. Journal of the Earth, 5, 81-95.

[86] Khavari, R., Arian, M. and Ghorashi, M. (2009) Neotectonics of the South Central Alborz Drainage Basin, in NW Tehran, N Iran. Journal of Applied Sciences, 9, 4115-4126. https://doi.org/10.3923/jas.2009.4115.4126

[87] Khavari, R., Ghorashi, M. and Arian, M. (2009) Assessment of Relative Active Tectonics, South Central Alborz (North Iran). EGU General Assembly Conference Abstracts, 11, 1137.

[88] Khavari, R., Ghorashi, M., Arian, M. and Khosrotehrani, K. (2010) Geomorphic Signatures of Active Tectonics in the Karaj Drainage Basin in South Central Alborz, N Iran. Geosciences, 19, 67-74.

[89] Khodabakhshnezhad, A. and Arian, M. (2016) Salt Tectonics in the Southern Iran. International Journal of Geosciences, 7, 367-377. https://doi.org/10.4236/ijg.2016.73029

[90] Khodabakhshnezhad, A., Arian, M. and Pourkermani, M. (2008) The Elements of Fold Style Analysis in the Asmari Anticline (Zagros). Journal of Sciences, 18, 129138.

[91] Khodabakhshnezhad, A., Arian, M. and Pourkermani, M. (2015) Folding Mechanism in the Asmari Anticline, Zagros, Iran. Open Journal of Geology, 5, 197-208. https://doi.org/10.4236/ojg.2015.54018

[92] Khodabakhshnezhad, A., Pourkermani, M., Arian, M., Matkan, A.A. and Charchi, A. (2015) Active Tectonics of Great Karounriver Basin. Geosciences, 24, 13-28.

[93] Khosroshahizadeh, S., Pourkermani, M., Almasian, M., Arian, M. and Khakzad, A. (2016) Lineament Patterns and Mineralization Related to Alteration Zone by Using ASAR-ASTER Imagery in Hize Jan-Sharaf Abad Au-Ag Epithermal Mineralized Zone (East Azarbaijan-NW Iran). Open Journal of Geology, 6, 232-250. https://doi.org/10.4236/ojg.2016.64021

[94] Khosroshahizadeh, S., Pourkermani, M., Almasiyan, M., Arian, M. and Khakzad, A. (2015) Evaluation of Structural Patterns and Related Alteration and Mineralization Zones by Using ASAR-ASTER Imagery in Siyahrood Area (East Azarbaijan-NW Iran). Open Journal of Geology, 5, 589-610. https://doi.org/10.4236/ojg.2015.59053

[95] Arian, M., Pourkermani, M., Qoreshi, M. and Ahmadnia, A. (2002). Salt Diapirism Along Mengharak Fault System. Proceedings of the 6th Symposium of Geological Society of Iran, Kerman University.

[96] Bagheri, M., Feiznia, S., Arian, M., Shabanian, R. and Mahari, R. (2013) Continental Trace Fossils in the Semnan Area (Northern Iran). Open Journal of Geology, 3, 5461. https://doi.org/10.4236/ojg.2013.32009

[97] Mahmoodi, M., Bahroudi, A., Ghorbani, M. and Arian, M. (2013) Preliminary Exploration of Copper Minerals in Jebal Barez Mountains, Iran. Open Journal of Geology, 3, 201-208. https://doi.org/10.4236/ojg.2013.33023

[98] Maleki, Z., Arian, M., Solgi, A. and Ganjavian, M.A. (2013) Sediment Deformations on Strike Slip Fault Blocks and Analogue Modeling: A Case Study of the Nezamabad Fault, Interior Fars, Zagros. Journal of Sciences (Islamic Azad University), 89, 
39-51.

[99] Maleki, Z., Arian, M. and Solgi, A. (2014) Structural Style and Hydrocarbon Trap of Karbasi Anticline, in the Interior Fars Region, Zagros, Iran. Solid Earth Discussions, 6, 2143-2167. https://doi.org/10.5194/sed-6-2143-2014

[100] Maleki, Z., Arian, M. and Solgi, A. (2015) Folding Pattern in the Fars Province, Zagros Folded Belt: Case Study on the Karbasi and Khaftar Anticlines, Interior Fars, Iran. Solid Earth Discussions, 7, 2347-2379. https://doi.org/10.5194/sed-7-2347-2015

[101] Maleki, Z., Arian, M., Solgi, A. and Ganjavian, M.A. (2014) The Elements of Fold Style Analysis in the Khaftar Anticline, Zagros, Iran. Open Journal of Geology, 4, 79-92. https://doi.org/10.4236/ojg.2014.43008

[102] Maleki, Z., Arian, M., Solgi, A. and Ganjavian, M.A. (2015) Elements of Fold Style Analysis in the Karbasi Anticline, Interior Fars Region, Zagros. Geosciences, 24, 293-302.

[103] Manafi, M. and Arian, M. (2008) basement Tectonics Investigation of Dezful Embayment, between Kazeron and Hendijan Faults. Journal of the Earth, 3, 47-61.

[104] Manafi, M., Arian, M., Raeesi, S. and Solgi, A. (2013) Tethys Subduction History in Caucasus Region. Open Journal of Geology, 3, 222-232. https://doi.org/10.4236/ojg.2013.33026

[105] Manuchehri, H., Arian, M., Ghorashi, M., Solgi, M. and Sorbi, A. (2015) Geomorphic Signatures of Active Tectonics in the Chalus Drainage Basin in the Alborz, Iran. Geosciences, 24, 273-280.

[106] Mardani, Z., Ghorashi, M. and Arian, M. (2011) Geomorphic Signatures of Active Tectonics in the Talaghanrud, Shahrudand Sefidrud Drainage Basins in Central Alborz, N Iran. Geosciences, 20, 159-166.

[107] Mashal, M., Pour Kermani, M., Charchi, A., Almasian, M. and Arian, M. (2013) Pattern of Structural Geology Underground in Eastern of North Dezfol Embayment. Advances in Environmental Biology, 7, 260-268.

[108] Mirzeinaliyazdi, S.H., Pourkermani, M., Arian, M. and Almasian, M. (2012) Geometrical Analysis of Fractures in Sabzevar Ophiolite Zone. Journal of Geotechnical Gology (Applied Geology), 7, 359-371.

[109] Mirzeinaliyazdi, S.H., Pourkermani, M., Arian, M. and Karkheiran, A. (2012) Determination of Stress Orientation in Sabzevar Ophiolite Zone in (Khorasan Razavi Province, Iran). Indian Journal of Science and Technology, 5, 3500-3505.

[110] Moghimi, H., Arian, M. and Sorbi, A. (2015) Fault Movement Potential of Marzanabad Area, North Alborz, Iran. Open Journal of Geology, 5, 126-135. https://doi.org/10.4236/ojg.2015.53012

[111] Mosavi, E. and Arian, M. (2015) Neotectonics of Kashaf Rud River, NE Iran by Modified Index of Active Tectonics (MIAT). International Journal of Geosciences, 6, 776-794. https://doi.org/10.4236/ijg.2015.67063

[112] Mosavi, E.J. and Arian, M. (2015) Neotectonics of Tabas Area, Central Iran by Index of Active Tectonics (IAT). Open Journal of Geology, 5, 209-223. https://doi.org/10.4236/ojg.2015.54019

[113] Mosavi, E.J., Arian, M., Ghorashi, M. and Nazemi, M. (2012) Measurements of Geomorphic Indices in Tabas Area. Journal of the Earth, 7, 213-225.

[114] Mousavi, E., Arian, M. and Ghorashi, M. (2017) Investigation of T Factor Variations along Atrak River to the Caspian Sea. Open Journal of Marine Science, 7, 3550. https://doi.org/10.4236/ojms.2017.71004

[115] Mousavi, E.J. and Arian, M. (2015) Tectonic Geomorphology of Atrak River, NE 
Iran. Open Journal of Geology, 5, 106-114. https://doi.org/10.4236/ojg.2015.53010

[116] Nazemi, M., Ghorashi, M., Ghassemi, M.R. and Arian, M. (2015) Morphotectonics Features of Alluvial Fans Associated with Active Tectonics (Shotori Mountains, East of Tabas-Central Iran). Geosciences, 24, 91-100.

[117] Noroozpour, H., Arian, M. and Sorbi, A. (2015) Fault Movement Potentials in the Tehran-Semnan Region (North Iran). Open Journal of Geology, 5, 281-290. https://doi.org/10.4236/ojg.2015.55025

[118] Nouri, R. and Arian, M. (2015) Structural Control on the Distribution of Hydrothermal Alteration Zones and Mineralization in Dastjerdeh Area Based on Remote Sensing Data, NW Iran. Bulletin of the Georgian National Academy of Sciences, 9, 79-86.

[119] Nouri, R. and Arian, M. (2017) Multifractal Modeling of the Gold Mineralization in the Takab Area (NW Iran). Arabian Journal of Geosciences, 10, 105. https://doi.org/10.1007/s12517-017-2923-2

[120] Nouri, R., Afzal, P., Arian, M., Jafari, M. and Feizi, F. (2013) Reconnaissance of Copper and Gold Mineralization Using Analytical Hierarchy Process in the Rudbar 1:100,000 Map Sheet, Northwest Iran. Journal of Mining and Metallurgy, 49, 9-19.

[121] Nouri, R., Jafari, M.R., Arian, M., Feizi, F. and Afzal, P. (2013) Correlation between $\mathrm{Cu}$ Mineralization and Major Faults Using Multifractal Modelling in the Tarom Area (NW Iran). Geologica Carpathica, 64, 409-416. https://doi.org/10.2478/geoca-2013-0028

[122] Nouri, R., Jafari, M.R., Arian, M., Feizi, F. and Afzal, P. (2013) Prospection for Copper Mineralization with Contribution of Remote Sensing, Geochemical and Mineralographical Data in Abhar 1:100,000 Sheet, NW Iran. Archives of Mining Sciences, 58, 1071-1084. https://doi.org/10.2478/amsc-2013-0074

[123] Omidali, M., Arian, M. and Sorbi, A. (2015) Neotectonics of Boroujerd Area, SW Iran by Index of Active Tectonics. Open Journal of Geology, 5, 309-324. https://doi.org/10.4236/ojg.2015.55028

[124] Pahlavani, A., Pourkermani, M., Arian, M. and Vahabzadeh, G. (2010) Structural Analysis of Emaft Fluorite Mine Region (Savaad Kuh Mazandaran). Journal of the Earth, 5, 75-81.

[125] Pazhoohan, M., Arian, M., Ghorashi, M. and Khosrotehrani, K. (2014) A Study of Drainage Pattern Responses to Active Tectonics in Tadvan Region, SW Iran. Geodynamics, 1, 36-41.

[126] Poroohan, N., Poukermani, M. and Arian, M. (2009) An Assessment on Correlations of Seismotectonic Parameters Preceding and Following Roudbar-Manjil Earthquake (Gilan, North of Iran). Australian Journal of Basic \& Applied Sciences, 3, 2643-2652.

[127] Poroohan, N., Pourkermani, M. and Arian, M. (2013) An Assessment of Relationship in F-Parameter and Paleostress Fields in Heterogeneous Lithologies: Roudbar Area (Northwest of Iran). Australian Journal of Basic \& Applied Sciences, 7, 933942.

[128] Pourkermani, M. and Arian, M. (1997) Salt Domes of Central Iran. Journal of Humanities, 3, 29-41.

[129] Pourkermani, M. and Arian, M. (1997) Seismotectonics. DezAb Consulting Engineers Company Press, Tehran, 270.

[130] Pourkermani, M. and Arian, M. (1998) Seismicity of Iran. Shahid Beheshti University Press, Tehran, 212.

[131] Pourkermani, M. and Arian, M. (1998) Tectonic Geomorphology of Salt Domes in 
West of Zanjan Province, Iran. Geographical Research, 47, 44-53.

[132] Pourkermani, M. and Arian, M. (1999) Structural Analysis of Halab Fault. Proceeding of the 3 rd Symposium of Geological Society of Iran, Shiraz, Iran, $31 \mathrm{Au}-$ gust-2 September 1999, 130-132.

[133] Pourkermani, M. and Arian, M. (2001) Analysis of Structural Specifications in Shah Neshin Area (The Eastern Border of Kordestan Province). Journal of Sciences, 11, 2859-2869.

[134] Pourkermani, M. and Arian, M. (2001) Structural Geomorphology of Northeastern Kurdistan. Journal of Humanities, 7, 37-48.

[135] Pourkermani, M., Mohajjel, M., Solgi, A., Arian, M. and Nadri, R. (2012) Active Tectonics of South Qom, a Hazard for New Residential Areas. Journal of Geotechnical Gology (Applied Geology), 8, 203-213.

[136] Pourkermani, M., Qorashi, M., Arian, M., Sorbi, A., Farokhnia, A. and Solgi, A., 2003. Structural Features in Western Part of the Lut Region. Iranian Journal of Geology, 1, 29-44.

[137] Qorashi, M. and Arian, M. (2011) Tectonics of Iran. Geologic Survey of Iran, Tehran, $336 \mathrm{p}$.

[138] Rafiee, P., Baghbani, D., Aghanabati, A. and Arian, M. (2015) Microbiostratigraphy and Lithostratigraphy of the Upper Permian Dalan Formation in Kuh-E-Surmeh (Zagros Basin, Southwest Iran). International Journal of Geography and Geology, 4, 68-73. https://doi.org/10.18488/journal.10/2015.4.4/10.4.68.77

[139] Rahimi, N. and Arian, M. (2014) Tectonic Geomorphplogy of Kangavar-Sosangerd Region, West Iran. Advances in Environmental Biology, 8, 119-124.

[140] Razaghian, G. and Arian, M. (2015) The Emergent Salt Diapirs in the East Zagros, Iran. Open Journal of Geology, 5, 718-726. https://doi.org/10.4236/ojg.2015.510063

[141] Rockwell, T.K., Keller, E.A. and Johnson, D.L. (1985) Tectonic Geomorphology of Alluvial Fans and Mountain Fronts near Ventura, California. In: Morisawa, M., Ed., Tectonic Geomorphology. Proceedings of the 15th Annual Geomorphology Symposium, Allen and Unwin Publishers, Boston, 183-207.

[142] Sadeghi, R., Saeedi, A., Arian, M., Ghorashi, M. and Solgi, A. (2015) Comparison of Strain Ellipsoid Shape in the South of Ardabil Range (NW), Based on the Results of the Magnetic Susceptibility Anisotropy and Paleostress Methods. Open Journal of Geology, 5, 611-622. https://doi.org/10.4236/ojg.2015.59054

[143] Shafiei Bafti, A., Pourkermani, M., Arian, M. and Ghorashi, M. (2014) The Study of Uplift Movements of Jorjafk Fault by North Front Davaran Mountains Rivers. Geosciences, 23, 115-122

[144] Sistanipour, A. and Arian, M. (2015) Geometric Analysis of Davaran Fault System, Central Iran. Open Journal of Geology, 5, 458-469. https://doi.org/10.4236/ojg.2015.56043

[145] Sorbi, A., Arian, M. and Pourkermani, M. (2009) The Movement Potential Evaluation of the Major Quaternary Faults in Tehran Quadrangle. Journal of the Earth, 19, 176-182.

[146] Sorbi, A., Arian, M. and Pourkermani, M. (2011) The Application of Geomorphic Indices to the Assessment of Relative Tectonic Activity Levels in Tehran Quadrangle. Journal of the Earth, 6, 1-9.

[147] Strahler, A.N. (1952) Hypsometric (Area-Altitude) Analysis of Erosional Topography. Geological Society of America Bulletin, 63, 1117-1142. https://doi.org/10.1130/0016-7606(1952)63[1117:HAAOET]2.0.CO;2

[148] Taherkhani, B., Nazari, H., Pourkermani, M. and Arian, M. (2015) Geometry and 
Recent Kinematics of the North Qazvin Fault: Morphotectonic Approach. Geosciences, 24, 29-38.

[149] Tajali, S. and Arian, M. (2016) Petrophysical Evaluation and the Effect of Shale Layers on Net Pay Zone Thickness in the Marun Oil Field, Iran. Open Journal of Geology, 6, 763-773. https://doi.org/10.4236/ojg.2016.68059

[150] Toudeshki, V.H. and Arian, M. (2011) Morphotectonic Analysis in the Ghezel Ozan River Basin, NW Iran. Journal of Geography and Geology, 3, 258-260. https://doi.org/10.5539/jgg.v3n1p258

[151] Toudeshki, V.H., Pourkermani, M., Arian, M. and Khosrotehrani, K.H. (2011) Influence of Structures on the Ghezel Ozan River. Geosciences, 21, 55-60.

[152] Vaseghi, H., Maleki, Z. and Arian, M. (2016) Structural Style in the Zagros FoldThrust Belt: The Gavbast Anticline, Coastal Fars. Open Journal of Geology, 6, 109116. https://doi.org/10.4236/ojg.2016.62011

Submit or recommend next manuscript to SCIRP and we will provide best service for you:

Accepting pre-submission inquiries through Email, Facebook, LinkedIn, Twitter, etc. A wide selection of journals (inclusive of 9 subjects, more than 200 journals)

Providing 24-hour high-quality service

User-friendly online submission system

Fair and swift peer-review system

Efficient typesetting and proofreading procedure

Display of the result of downloads and visits, as well as the number of cited articles

Maximum dissemination of your research work

Submit your manuscript at: http://papersubmission.scirp.org/

Or contact ojms@scirp.org 